\title{
Studi Perencanaan Dinding Penahan Sebagai Upaya Pengendalian Banjir Sungai Meduri Kabupaten Pekalongan Jawa Tengah
}

\author{
Study on Retaining Wall Design for Flood Control at Meduri River Pekalongan \\ Regency Central Java
}

\section{Ekhsan Zainuri $\left.{ }^{1 *}\right)$, Heri Suprijanto1, Dian Sisinggih ${ }^{1}$}

${ }^{1}$ Jurusan Teknik Pengairan, Fakultas Teknik, Universitas Brawijaya, Malang 65145, Indonesia

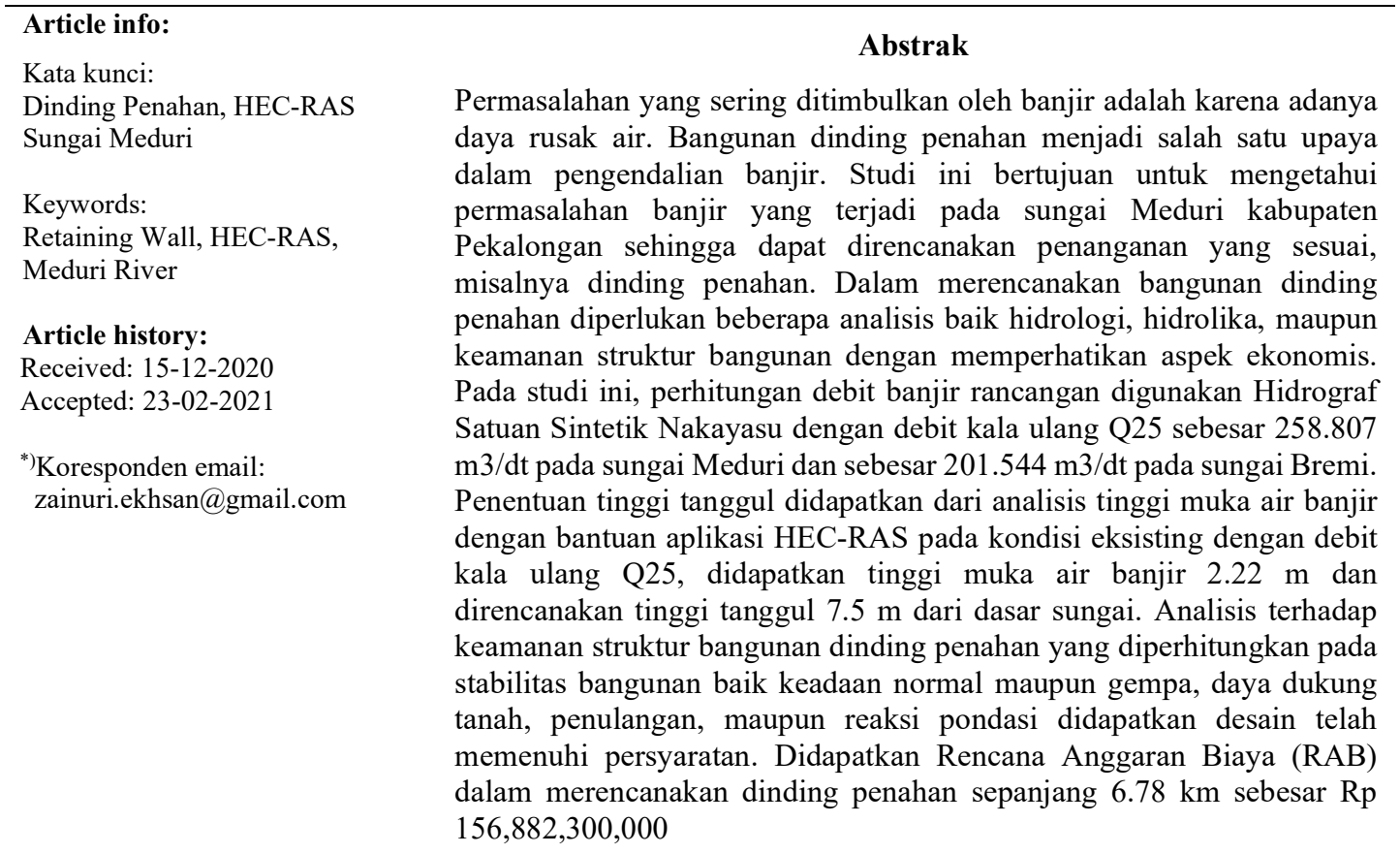

\begin{abstract}
Flooding is often causing a problem because of its destructive power. Retaining wall structure is one among the efforts to control the floods. This study aims to determine the problem of flooding that occurs in the Meduri river in Pekalongan regency so that an appropriate treatment can be planned, for example a retaining wall. Several analysis are required in order to plan retaining wall structure, such as hydrology, hydraulics, and safety factor of its structure regarding to economic aspect. This study is using a Nakayasu Synthetic Unit Hydrograph for its design flood discharge with Q25 return flowrate at $258.807 \mathrm{~m} 3 / \mathrm{s}$ in Meduri River and $201.544 \mathrm{~m} 3 / \mathrm{s}$ in Bremi River. The height of the embankment is obtained from analysis of flood water level using HEC-RAS with this following existing conditions: Q25 return flowrate, flood water level at $2.22 \mathrm{~m}$, and height of dyke is planned at 7.5 from riverbed. The safety analysis of this retaining wall is calculated by stability normal, earthquake, soil bearing capacity, reinforcement, and also foundation reaction are already meet the criteria standard. The budget plan at this planning of $6.78 \mathrm{~km}$ retaining wall is IDR $156,882,300,000$.
\end{abstract}

\footnotetext{
Kutipan: Zainuri, E., Suprijanto, H., \& Sisinggih, D. (2021). Studi Perencanaan Bangunan Dinding Penahan Sebagai Upaya Pengendalian Banjir Sungai Meduri Kabupaten Pekalongan Jawa Tengah. Jurnal Teknik Pengairan. https://doi.org/10.21776/ub.pengairan.2021.012.01.01
} 


\section{Pendahuluan}

Daerah Aliran Sungai (DAS) merupakan wilayah dengan punggung-punggung gunung maupun bukit sebagai pembatasnya dimana hujan yang turun akan ditampung serta dialirkan melewati anakanak sungai menuju sungai uatama (Asdak, 1995).

Tingginya kebutuhan manusia dalam memenuhi kebutuhan hidup mengakibatkan tingginya resiko perubahan tata guna lahan akibat adanya aktivitas eksploitasi DAS. Salah satu akibat yang dapat ditimbulkan adalah berkurangnya daerah resapan air (infiltrasi) pada kawasan hulu dan memperbesar nilai koefisien limpasan air hujan, dengan seperti ini resiko banjir sangat mungkin terjadi. Banjir pada umumnya memiliki unsur daya rusak air dikarenakan adanya energi yang besar yang dapat memberi dampak seperti rusaknya bangunan sekitar sungai dan menyebabkan kerugian secara material maupun sosial.

Pengendalian banjir, seperti ditulis Kodoatie dan Sugiyanto (Kodoatie \& Syarief, 2010), merupakan suatu yang kompleks karena melibatkan banyak disiplin imu teknik di lapangan, serta berbagai ilmu kebijakan publik dan manajemen manusia di ranah perumusan. Selain itu, keberhasilan program pengendalian banjir juga amat bergantung pada aspek eksternal seperti sosial, ekonomi, lingkungan, institusi, kelembagaan, hukum, dan lainnya.

Kabupaten Pekalongan bagian utara merupakan kawasan muara dengan intensitas kejadian banjir yang hampir terjadi setiap tahunnya. Salah satu sungai yang difungsikan menjadi saluran pembuangan utama adalah sungai Meduri. Semakin dangkal dan menyempitnya sungai Meduri ditambah dengan adanya pengaruh back water atau pengaruh pasang air laut menjadikan kapasitas tampung sungai Meduri menjadi berkurang tiap tahunnya, sehingga diperlukan upaya penanggulangan agar tidak terjadi limpasan dari sungai.

Kabupaten Pekalongan merupakan salah satu wilayah administratif di Provinsi Jawa Tengah yang endemik rob (Nasrullah, 2013). Nasrullah menjelaskan bahwa setiap tahunnya banjir rob yang ada di Pekalongan bertambah luas sebagai akibat dari pemanasan global, degradasi (penurunan tanah), dan juga abrasi pantai. Degradasi tanah terjadi sebagai akibat meningkatnya jumlah masyarakat dan pembangunan fisik yang tak pernah berhenti. Wilayah terdampak rob di Kabupaten Pekalongan, antara lain, kecamatan Tirto, Wiradesa, Siwalan dan Wonokerto yang berbatasan langsung dengan Laut Jawa di sebelah utara.

Menurut Kasbullah dkk, wilayah pesisir Pekalongan memang tergolong pada elevasi yang rendah yakni +0 hingga +4 meter di atas permukaan laut yang mengakibatkan pasang surut air laut dapat mencapai daratan. Beberapa dampak negatif sebagai akibat adanya rob di Kabupaten Pekalongan seperti kerusakan lahan pertanian, kerusakan permukiman dan jalan, terganggunya sanitasi masyarakat, kerusakan tambak, hingga rusaknya peralatan yang berbahan logam seperti sepeda motor (Kasbullah et al., 2014).

Tujuan dari adanya studi ini adalah untuk mengetahui besarnya debit banjir rancangan dan kondisi eksisting profil aliran pada Sungai Meduri Kabupaten Pekalongan apakah sungai mampu mengalirkan debit banjir, selain itu untuk mengetahui perencanaan bangunan dinding penahan sebagai upaya pengendalian banjir dan untuk mengetahui besar Rancangan Anggaran Biaya (RAB) yang dibutuhkan untuk merencanakan bangunan dinding penahan pengendalian banjir untuk Sungai Meduri, Kabupaten Pekalongan.

\section{Bahan dan Metode}

\subsection{Lokasi Studi}

Sub DAS Meduri-Bremi terletak pada terletak pada 6 kecamatan, 4 kecamatan pada Kabupaten Pekalongan yakni; Kecamatan Tirto, Kecamatan Kedungwuni, Kecamatan Karang Dadap, Kecamatan Buaran, dan 2 kecamatan pada Kota Pekalongan yakni; Kecamatan Pekalongan Barat, dan Kecamatan Pekalongan Selatan dengan luasan mencapai $53.95 \mathrm{~km}^{2}$. Panjang sungai yang ada yakni sungai Meduri sepanjang $8.152 \mathrm{~km}$ dan sungai Bremi $9.46 \mathrm{~km}$.

Gambar 1 merupakan tampilan citra satelit lokasi studi dengan menggabungkan peta batas luas Sub DAS Meduri dan Sub DAS Bremi serta alur sungai yang dimodelkan menggunakan HEC-RAS versi 5.0.7. Dari gambar diperlihatkan lokasi studi yaitu Kabupaten Pekalongan yang berada pada wilyah pesisir laut jawa. Sungai Bremi dan Meduri merupakan anak sungai dari Sungai Singkarang 
pada Daerah Aliran Sungai (DAS) Singkarang. Sungai ini merupakan satu dari sungai yang masuk dalam Wilayah Sungai Pemali-Juana.

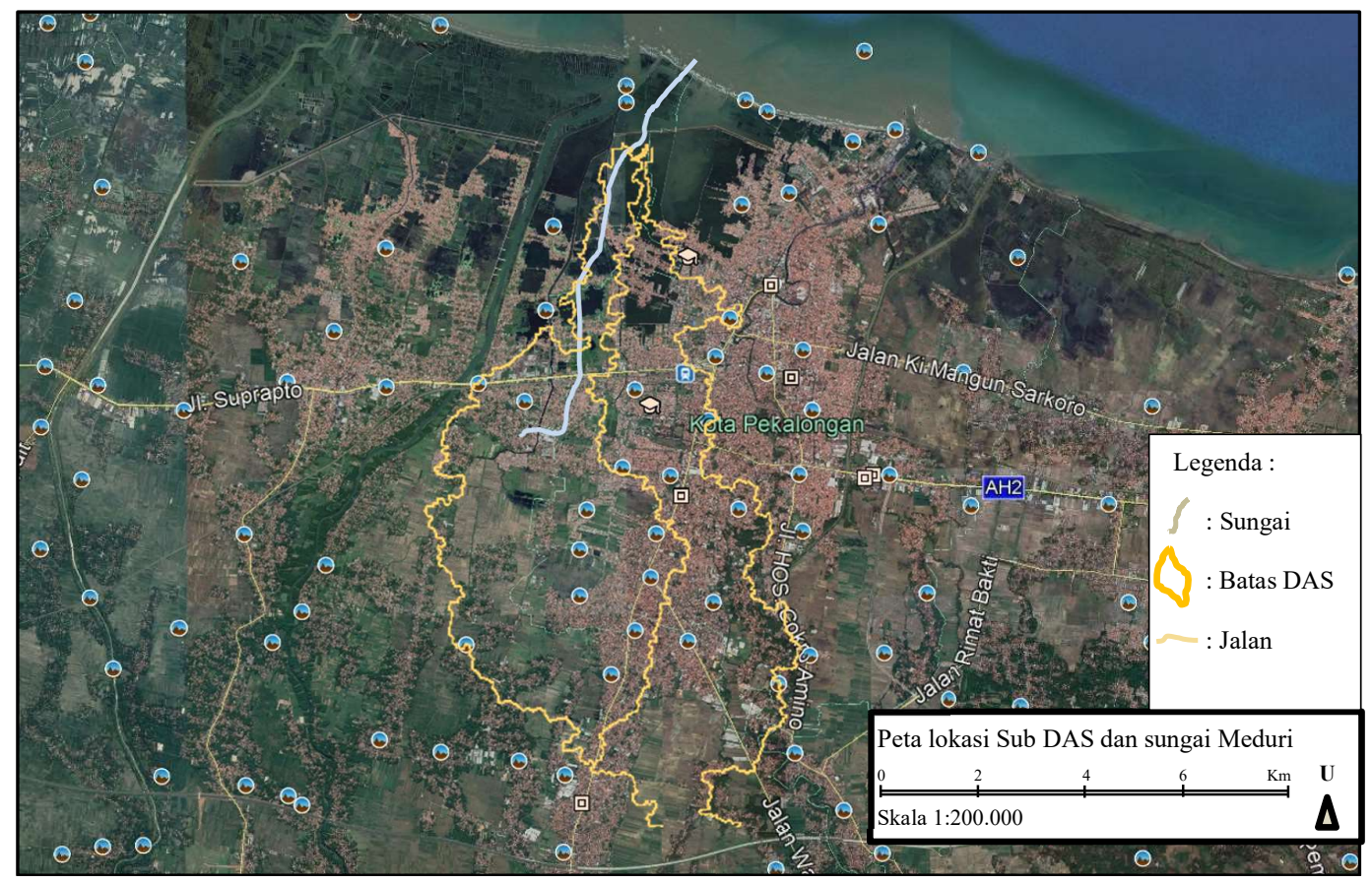

Gambar 1. Lokasi studi Sub DAS dan Sungai Meduri Kabupaten Pekalongan, Jawa Tengah

\subsection{Metode Pengerjaan}

Dalam metode pengerjaan studi ini dijelaskan berupa langkah-langkah dalam merencanakan Bangunan Dinding Penahan, sebagai berikut:

1. Pengambilan data-data yang diperoleh yakni data Hidrologi dari Stasiun Hujan, Peta Situasi Daerah aliran Sungai (DAS), Pengukuran penampang sungai, Pasang Surut Air Laut, dan Sifatsifat Tanah.

2. Analisa Hidrologi

Perhitungan hidrologi merupakan bagian awal pada perencanaan bangunan keairan. Dalam hal ini, aspek analisa yang dihasilkan dapat menunjang perencanaan bangunan hidrolik yaitu besaranya rancangan hujan, debit banjir, serta unsur hidrologi yang lain (C. D. Soemarto. Ir. B.I.E. DIPL.H., 1995)

a. Perhitungan Hujan Rata-Rata Daerah menggunakan metode Aritmatika dan metode Poligon Thiessen

b. Perhitungan Analisa frekuensi dan curah hujan rancangan untuk memperkirakan debit aliran menggunakan distribusi Log Pearson Type III.

c. Uji kesesuaian distribusi digunakan untuk mengetahui jenis sebaran teoritis yang dipilih suatu data telah sesuai tidak, dengan menggunakan Uji Chi-Square untuk mengetahui uji distribusi terhadap penyimpangan data ke arah vertikal dan Uji Smirnov-Kolmogorov untuk mengetahui uji distribusi terhadap penyimpangan data ke arah horizontal

d. Perhitungan hujan efektif jam-jaman dengan metode PSA 007.

e. Perhitungan debit banjir rencana dengan metode Hidrograf Satuan Sintetis Nakayasu.

3. Perhitungan rencana penanganan banjir

a. Menganalisa profil aliran sungai dengan Software HEC-RAS versi 5.0.7 untuk mengetahui daya tampung, titik-titik kritis yang rawan terjadi limpasan, serta pengaruh pasang surut air laut.

b. Merencanakan bangunan dinding penahan sebagai upaya pengendalian banjir.

c. Menganalisa profil aliran sungai dengan menggunakan bantuan Software HEC-RAS versi 5.0.7 setelah adanya rencana bangunan dinding penahan. 
4. Analisis stabilitas bangunan dinding penahan.

a. Perhitungan stabilitas bangunan dinding penahan sebagai upaya pengendalian banjir.

b. Perhitungan penulangan pada dinding penahan sebagai upaya pengendalian banjir

c. Perhitungan pondasi tiang pancang bangunan.

5. Analisis besaran Rencana Anggaran Biaya.

\subsection{Data-data Penelitian}

Langkah awal dalam merencanakan bangunan dinding penahan sebagai upaya pengendali banjir adalah dengan mengumpulkan data-data yang diperlukan, yakni data pengukuran curah hujan dari 3 stasiun hujan (Pekalongan, Dalektukang, dan Pesantren Kletak) dengan memakai 15 tahun pengukuran mulai tahun 2004 sampai dengan 2018, data topografi DAS yang meliputi Luas DAS dan panjang sungai, data pasang surut air laut, data pengukuran potongan memanjang dan melintang sungai, serta data karakteristik tanah. Data-data di atas didapatkan dari PT. Amarta Group Consultant Engineering pada laporan detail desain pengendalian banjir dan rob pekalongan (Utama, 2017).

\subsection{Analisis data curah hujan rerata daerah menggunakan metode Poligon Thiessen}

Metode Poligon Thiessen akan memberikan proporsi luas pengaruh stasiun hujan dengan mengakomodasikan ketidak seragaman jarak, sehingga perhitungan memberikan hasil yang akurat. Tinggi curah hujan rata-rata daerah menggunakan poligon Thiessen dihitung dengan persamaan di bawah ini. (C. D. Soemarto. Ir. B.I.E. DIPL.H., 1995)

$$
\bar{R}=\frac{A_{1} R_{1}+A_{2} R_{2}+\ldots+A_{n} R_{n}}{A_{1} A_{2}+\ldots+A_{n}}=\frac{\sum A_{j} R_{j}}{A_{i}}
$$

dengan:

$\bar{R} \quad=$ tinggi curah hujan rata-rata daerah $(\mathrm{mm})$

$R_{1}, R_{2}, R_{\mathrm{n}}, \quad=$ curah hujan pada setiap stasiun hujan $(\mathrm{mm})$

$A_{1}, A_{2}, A_{n} \quad=$ luas pengaruh stasiun hujan pada-n $\left(\mathrm{km}^{2}\right)$

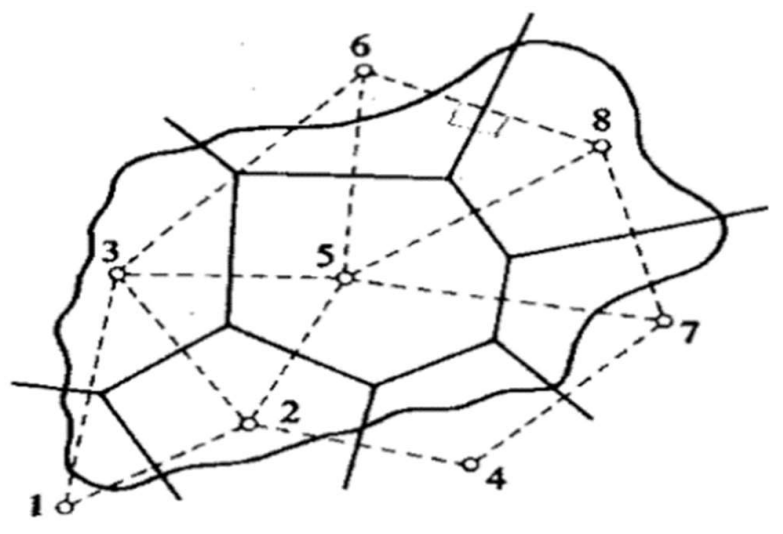

Gambar 2. Poligon Thiessen

\subsection{Debit Banjir Rancangan}

Debit banjir rancangan adalah nilai besarnya debit maksimum yang dapat terjadi pada suatu daerah dengan kala ulang kejadian tertentu. Dalam memperhitungkan nilai debit banjir rancangan diperlukan terlebih dahulu analisis curah hujan jam-jaman, dalam studi ini digunakan metode PSA 007 dikarenakan karakteristik distribusi hujan yang sesuai dengan kondisi alam di Indonesia. Penaksiran besarnya nilai debit banjir rancangan digunakan perhitungan Hidrograf Satuan Sintetik Nakayasu dengan input parameter yaitu luas DAS, panjang sungai, dan dengan nilai $\alpha$ yang disesuaikan dengan jenis dan karakteristik hidrograf banjir pada sungai (C. D. Soemarto. Ir. B.I.E. DIPL.H., 1995). 


\subsection{Analisis Profil Aliran Menggunakan HEC-RAS}

Analisis profil aliran sungai digunakan untuk mengetahui elevasi muka air sungai pada kondisi tertentu berdasarkan input data debit banjir rancangan dengan kala ulang tertentu agar dapat diketahui ada tidaknya limpasan yang terjadi pada sungai, sehingga dapat ditentukan bagaimana alternatif yang direncanakan dalam perbaikan alur sungai. Dalam studi ini analisis profil aliran sungai digunakan bantuan Software HEC-RAS versi 5.0.7 yang merupakan perangkat lunak yang dikembangkan oleh Bill S. Eichert dari The Hydrologic Engineering Center (Army Corps of Engineers, 2010).

\subsection{Perencanaan Dinding Penahan}

Bangunan dinding penahan direncanakan sepanjang alur sungai yang hendak dilakukan perbaikan. Fungsi utama bangunan ini untuk menampung kapasitas debit banjir untuk mencegah terjadinya limpasan. Dinding penahan direncanakan menggunakan kontruksi beton bertulang dengan tipe kantilever. Karakteristik tanah baik tanah asli maupun tanah timbunan, tinggi muka air sungai, dan tinggi muka air tanah berpengaruh terhadap dimensi bangunan yang direncanakan dengan memperhatikan ketentuan tinggi jagaan. Perhitungan stabilitas bangunan dinding penahan harus memenuhi persyaratan terhadap guling, geser, eksentrisitas, dan daya dukung tanah baik kondisi normal maupun kondisi gempa, sesuai pada acuan BSN dan Terzaghi (NASIONAL, 2017) (Hardiyatmo, 2003).

Sedangkan analisis penulangan mengacu pada peraturan SNI 2847:2013 (Setiawan, 2016) khususnya adalah Bab 14 tentang Dinding Struktural yang mana penulangan di bagi menjadi beberapa bagian yaitu pada dinding, kaki (toe), dan tumit (heel) agar didapatkan desain yang ekonomis. Analisis perhitungan tiang pancang diperlukan apabila struktur tanah di bawah bangunan tidak mampu menahan beban yang terjadi, sehingga dapat terjadi kegagalan struktur dengan amblasnya bangunan. Adanya tiang pancang dapat memindahkan beban-beban dari konstruksi di atasnya (super structure) ke lapisan tanah yang lebih dalam, dengan memperhitungkan kekuatan bahan tiang, kapasitas daya dukung, gaya tarik (pull out force), dan pergeseran horizontal (defleksi) pada tiang.

\subsection{Rencana Anggaran Biaya (RAB)}

Dalam menghitung rencana anggaran biaya perencanaan dinding penahan diperlukan data harga upah kerja dan bahan sesuai dengan kebutuhan kontruksi, yang didapatkan dari standar biaya dan harga satuan kabupaten Pekalongan. Setelah itu dilakukan perhitungan analisa harga satuan pekerjaan yang dibedakan pada setiap jenis pekerjaan yang disesuaikan dengan harga koefisien yang mengacu pada Permen PU No 112013 - Pedoman Bahan Konstruksi Bangunan dan Rekayasa SipilBidang Sumber Daya Air maka didapatkan harga satuan yang digunakan untuk menghitung rencana anggaran biaya. (Umum, P. M. P., \& Rakyat, 2013)

\section{Hasil dan Pembahasan}

\subsection{Analisis Hidrologi}

Stasiun pengukuran hujan pada setiap titik perlu dilakukan pengukuran luasan pengaruh pada daerah aliran sungai untuk memberikan proporsi hujan yang akurat, dalam hal ini penentuan hujan rata-rata daerah menggunakan metode Poligon Thiessen. Tabel 1 menyajikan prosentase koefisien luasan $(\mathrm{Kr})$ dengan luas pengaruh stasiun hujan dengan prosentase dalam \%.

Analisa frekuensi curah hujan rancangan berupa jumlah hujan yang terjadi selama satu hari dalam satuan millimeter digunakan metode Log Pearson tipe III yang dijelaskan oleh Soewarno. Nilai logaritma yang ada digunakan untuk memperkirakan debit aliran dalam berbagai kala ulang yang telah direncanakan (Soewarno, 1995).

Perhitungan logaritma hujan $\mathrm{P}$ dengan waktu balik yang dikehendaki dengan persamaan di bawah ini dengan hasil perhitungan disajikan pada Tabel 2, dimana logaritma curah hujan rancangan dalam satuan $\mathrm{mm}, \overline{\log X}=$ logaritma rata-rata curah hujan, $k=$ konstanta, $S d=$ standar deviasi (Soewarno, 1995):

$$
\log \mathrm{X}=\overline{\log \mathrm{X}}+k(S d)
$$


Tabel 1. Perhitungan koefisien Thiessen

\begin{tabular}{clccc}
\hline \hline No & Nama Stasiun & Luas $\left(\mathbf{k m}^{2}\right)$ & $\mathbf{K r}$ & $\begin{array}{c}\text { Persentase Pengaruh } \\
\mathbf{( \% )}\end{array}$ \\
\hline 1 & Pekalongan & 20.26 & 0.376 & 37.554 \\
2 & Delegtukang & 8.34 & 0.155 & 15.451 \\
4 & Pesantren Kletak & 25.35 & 0.470 & 46.995 \\
\hline & Jumlah & 53.95 & 1 & 100 \\
\hline \hline
\end{tabular}

Tabel 2. Perhitungan distribusi frekuensi Log Pearson III

\begin{tabular}{cccccc}
\hline \hline $\operatorname{Tr}(\mathbf{T h})$ & $\operatorname{Pr}(\%)$ & $\mathbf{K}$ & $\mathbf{K} . \mathbf{S d} \log \mathbf{X}$ & $\log \mathbf{X}_{\text {rancangan }}$ & $\mathbf{X}_{\text {rancangan }}$ \\
\hline 20 & 5 & 1.490 & 0,199 & 2.284 & 192.154 \\
25 & 4 & 1.617 & 0,216 & 2.301 & 199.847 \\
50 & 2 & 1.851 & 0,248 & 2.332 & 214.770 \\
100 & 1 & 2.051 & 0,275 & 2.359 & 228.471 \\
200 & 0.5 & 2.228 & 0,298 & 2.382 & 241.240 \\
\hline \hline
\end{tabular}

Dari Tabel 2 di atas, perhitungan curah hujan rancangan distribusi frekuensi menggunakan Log Pearson tipe III diperlukan uji kesesuaian distribusi frekuensi. Hasil yang diperoleh pada Uji Smirnov-Kolmogorof didapatkan pada peluang 1\% D kritis sebesar 0.404 dan untuk peluang 5\% didapatkan $\mathrm{D}_{\text {kritis }}$ sebesar 0.338 yang mana $\mathrm{D}_{\text {max }}$ hitung didapatkan sebesar 0.927 maka dari itu Uji dikatakan diterima. Sedangkan pada Uji Chi-Square didapatkan pada peluang $1 \% \mathrm{D}_{\text {kritis }}$ sebesar 9.21 dan untuk peluang 5\% didapatkan $\mathrm{D}$ kritis sebesar 5.99 yang mana $\mathrm{D}$ max hitung didapatkan sebesar 4.667 maka dinyatakan diterima untuk kedua peluang (Soewarno, 1995).

Analisis hujan jam-jaman metode PSA 007 adalah memperkirakan prosentase hujan yang jatuh pada tiap jamnya, dimana curah hujan rancangan dikalikan faktor koefisien pengaliran dan didapatkan nilai distribusi hujannya dengan durasi waktu selama enam jam (Syarifudin, A., 2017).

Untuk memperoleh nilai distribusi hujan efektif jam jaman, perlu dikalikan tabel PSA 007 dengan curah hujan rancangan $\left(\mathrm{R}_{\text {ranc }}\right.$ ) dalam $\mathrm{mm}$ dan besaran koefisien limpasan $(\mathrm{C})$ sehingga besarnya hujan pada tiap jam selama 6 jam dan pada kala ulang tertentu dapat diketahui. Hasil perhitungan ditampilkan pada Tabel.3

Tabel 3. Distribusi hujan efektif jam - jaman metode PSA 007 sub DAS Meduri

\begin{tabular}{ccccc}
\hline \hline $\mathbf{T r})$ & $\mathbf{2 0}$ & $\mathbf{2 5}$ & $\mathbf{5 0}$ & $\mathbf{1 0 0}$ \\
\hline $\mathbf{R}_{\text {Ranc }}(\mathbf{m m})$ & 192.154 & 199.847 & 214.770 & 228.471 \\
\hline $\mathbf{C})$ & 0.592 & 0.597 & 0.605 & 0.612 \\
\hline $\mathbf{R}_{\mathbf{n}}(\mathbf{m m})$ & 113.839 & 119.322 & 130.005 & 139.864 \\
\hline 1 & 4.554 & 4.773 & 5.200 & 5.595 \\
2 & 14.002 & 14.677 & 16.901 & 18.602 \\
3 & 76.272 & 79.946 & 84.503 & 89.513 \\
4 & 9.676 & 10.381 & 13.000 & 14.965 \\
5 & 4.554 & 4.773 & 5.200 & 5.595 \\
6 & 4.554 & 4.773 & 5.200 & 5.595 \\
\hline \hline
\end{tabular}

Untuk mendapatkan hasil yang akurat dalam menghitung debit banjir rancangan, maka sub DAS Meduri dan Bremi dihitung terpisah dimulai dari perhitungan hujan jam-jaman metode PSA 007 
dengan cara yang sama. Pengalihragaman hujan akibat adanya tampungan pada daerah pengaliran merupakan prinsip dasar Hidrograf, dalam perhitungan debit banjir rancangan digunakan metode Hidrograf Satuan Sintetik Nakayasu. Nakayasu dari Jepang telah menyelidiki hidrograf satuan pada beberapa sungai di Jepang. Ia membuat rumusan hidrograf satuan sintetik dari hasil penyelidikannya tersebut dengan input parameter yaitu :

$$
\begin{aligned}
\text { Luas DAS Meduri } & =22.704 \mathrm{~km}^{2} \\
\text { Panjang Sungai Utama }(\mathrm{L}) & =7.11 \mathrm{~km} \\
(\alpha) \text { dengan coba-coba } & =2.5
\end{aligned}
$$

Digunakan persamaan Nakasayu dengan memperoleh nilai debit puncak banjir adalah mengalikan hujan satuan $(\mathrm{mm})$ dengan luasan DAS serta koefisien pengaliran dan dibagi dengan tenggang waktu dari permulaan hujan sampai puncak banjir (jam) yang dikalikan waktu penurunan debit dari puncak sampai $30 \%$ dari debit puncak.

Berdasarkan parameter di atas, nilai debit banjir pada unit hidrograf dapat diidentifikasikan sesuai karakteristik yang menghasilkan periode ulang 20, 25, 50, dan 100.

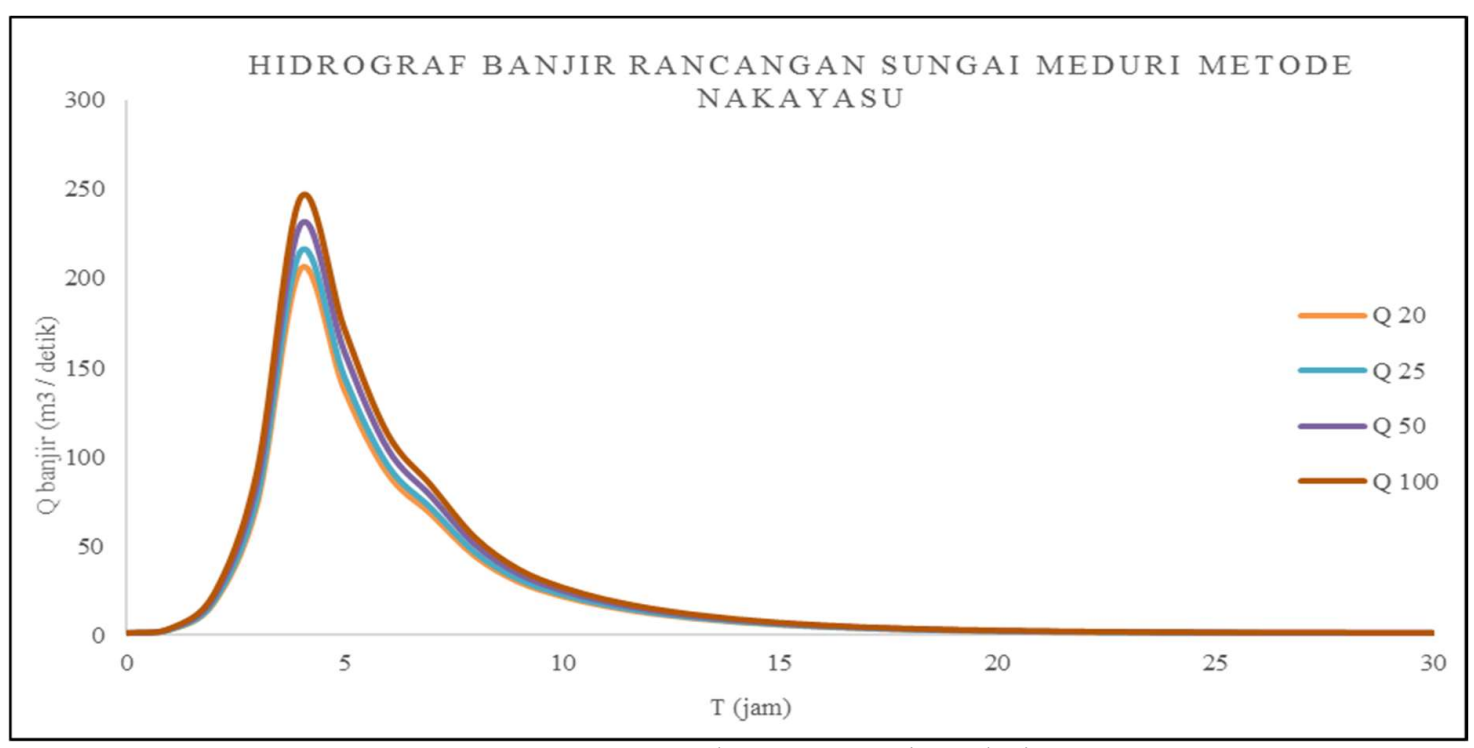

Gambar 3. HSS Nakayasu sungai Meduri

Gambar 3 dapat menjelaskan karakteristik hidrograf sungai Meduri, dimana bila hujan yang jatuh pada DAS yang menjadi debit banjir kecenderungan memiliki waktu yang singkat dengan di tunjukan puncak hidrograf yang mendekati jam-jam awal.

\subsection{Analisis Profil Aliran}

Analisis yang dilakukan adalah menggunakan bantuan Software HEC RAS versi 5.0.7 untuk mengidentifikasi titik-titik rawan di sepanjang alur sungai dengan melihat elevasi tanggul kiri maupun kanan sungai apakah terjadi limpasan atau tidak. Analisis ini dilakukan pada dua kondisi, yaitu kondisi eksisting dan kondisi desain dengan input debit kala ulang Q25 Sungai Meduri 215.571 $\mathrm{m}^{3} / \mathrm{dt}$ dan Sungai Bremi adalah sebesar $201.291 \mathrm{~m}^{3} / \mathrm{dt}$ serta dipadukan dengan data pasang surut air laut (stage hydrograph). Running aliran yang digunakan adalah memakai unsteady flow.

Geometri data yang dimasukan dalam HEC RAS disesuaikan dengan data pengukuran potongan melintang sungai. Sedangkan nilai kekasaran manning yang digunakan dalam analisis adalah menggunakan nilai $\mathrm{N}$ manning kombinasi $(\mathrm{Nc})$ diperoleh menggunakan rumus dari Horton dan Einstein, 1942 (Chow, 1985). 


$$
\mathrm{n}_{\text {composite }}=\left(\frac{\sum_{\mathrm{i}=1}^{\mathrm{n}}\left(\mathrm{P}_{\mathrm{i}} \mathrm{n}_{\mathrm{i}}^{1.5}\right)}{\mathrm{P}_{\text {total }}}\right)^{\frac{2}{3}}
$$

Dari rumus di atas dalam mencari nilai $\mathrm{n}$ composite diperlukan nilai manning (n) dari dasar sungai yang disesuaikan pada kondisi lapangan dan dipadukan pada tabel nilai koefisien kekasaran manning pada buku Ven Te Chow, 1985, sedangkan panjang sisi (P) disesuaikan dengan panjang sisi kiri maupun kanan sungai sehingga didapatkan nilai yang akurat sebagai pengaruh adanya berbedaan material dasar. Perhitungan nilai Nilai kekasaran manning kombinasi $(\mathrm{Nc})$ dilakukan sepanjang alur sungai. Untuk mempermudah dalam perhitungan nilai kekasaran manning kombinasi, setidaknya pada bagian hulu, tengah, dan hilir sungai dihitung agar dapat mewakili kondisi alami sungai. Perhitungan dilakukan pada kondisi eksisting dan kondisi desain (Normalisasi) dengan input nilai manning dan panjang sisi yang berbeda.

Hasil running kondisi eksisting diperoleh hampir disepanjang sungai yang dimodelkan terjadi limpasan dengan tinggi maksimum adalah setinggi $2.22 \mathrm{~m}$ pada lokasi patok M.8. Sedangkan tinggi rata-rata limpasan adalah $1.42 \mathrm{~m}$. Maka dari itu diperlukan upaya perbaikan alur sungai yang terlebih dahulu dimodelkan pada $H E C R A S$.

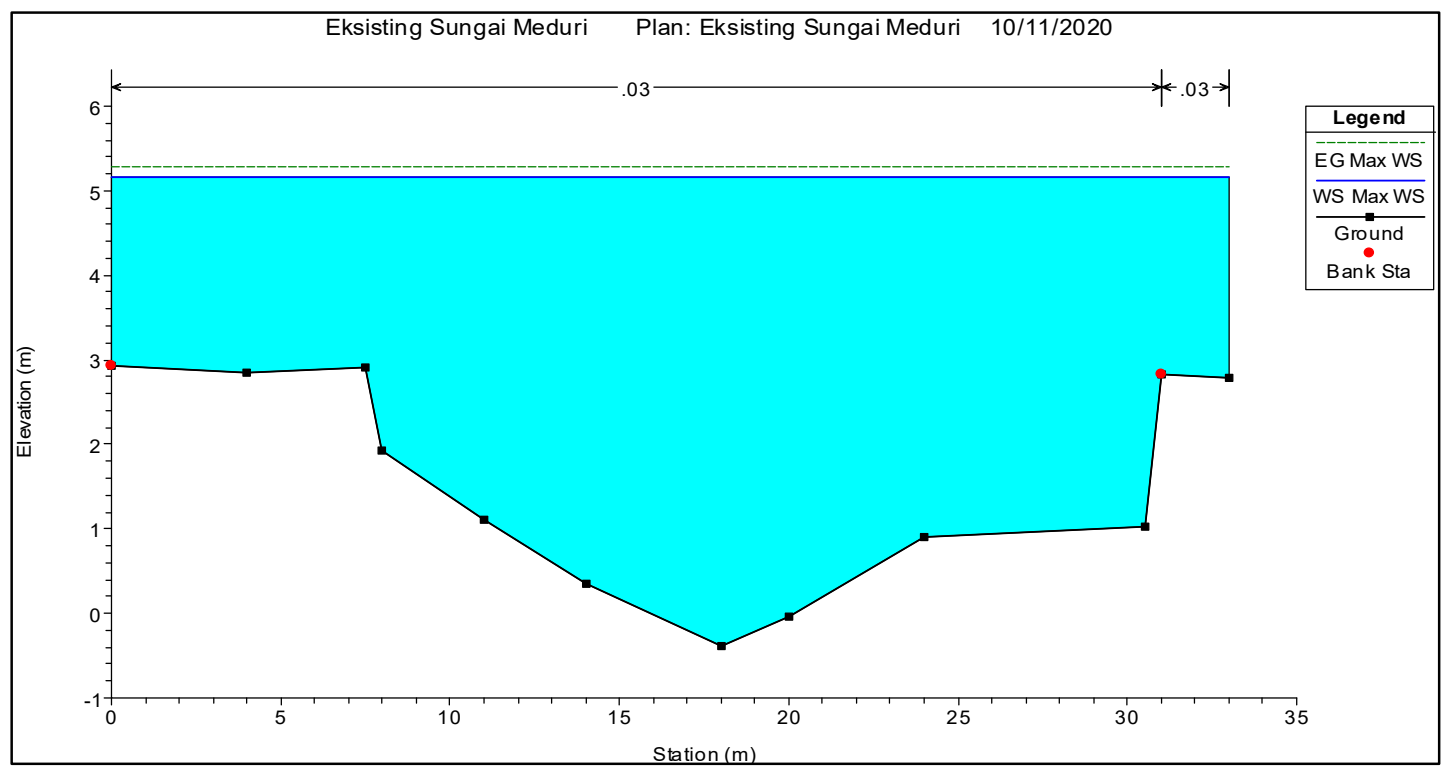

Gambar 4. Tinggi limpasan maksimum pada patok M. 8

Pada Gambar 4 diperlihatkan tinggi limpasan air sungai Meduri tertinggi pada kondisi eksisting, dimana nilai limpasan mencapai tinggi $2.22 \mathrm{~m}$ terhitung dari puncak tanggul eksisting (tanggul lama) dan tinggi muka air banjir pada elevasi +5.15 . Limpasan yang terjadi cukup tinggi sebagai akibat dari perubahan alur sungai Meduri oleh adanya pendangkalan dasar sungai, sehingga sungai tidak mampu menampung debit banjir yang terjadi.

Pada Gambar 5 diperlihatkan potongan memanjang alur sungai Meduri pada kondisi eksisting secara keseluruhan. Limpasan terjadi di hampir seluruh alur sungai yang mana garis air sungai yang berwarna biru melebihi garis tanggul eksisting yang ditandai dengan garis putus-putus (ROB dan LOB). Pada bagian hilir, air sungai bertemu dengan air laut pada elevasi $+1,89$ yang mana merupakan air laut paling tinggi sebagai akibat adanya pengaruh pasang surut air laut. Pasang air laut tertinggi memberikan pengaruh pada tinggi limpasan sungai. Air laut secara langsung memberikan tekanan pada air sungai yang mengakibatkan laju aliran pada sungai Meduri menjadi lambat. Dari gambar potongan memanjang di atas bagian hilir terlihat dasar alur sungai yang lebih tinggi daripada dibagian tengah sungai. Berdasarkan laporan Penyusunan Review RPIJM Bidang Cipta Karya 
Kabupaten Pekalongan tahun 2016, sungai meduri setiap tahunnya terjadi pendangkalan. Sehingga dengan pemodelan $H E C-R A S$ ini dapat diketahui pengaruh pendangkalan terhadap limpasan sungai meduri (Umum, 2016).

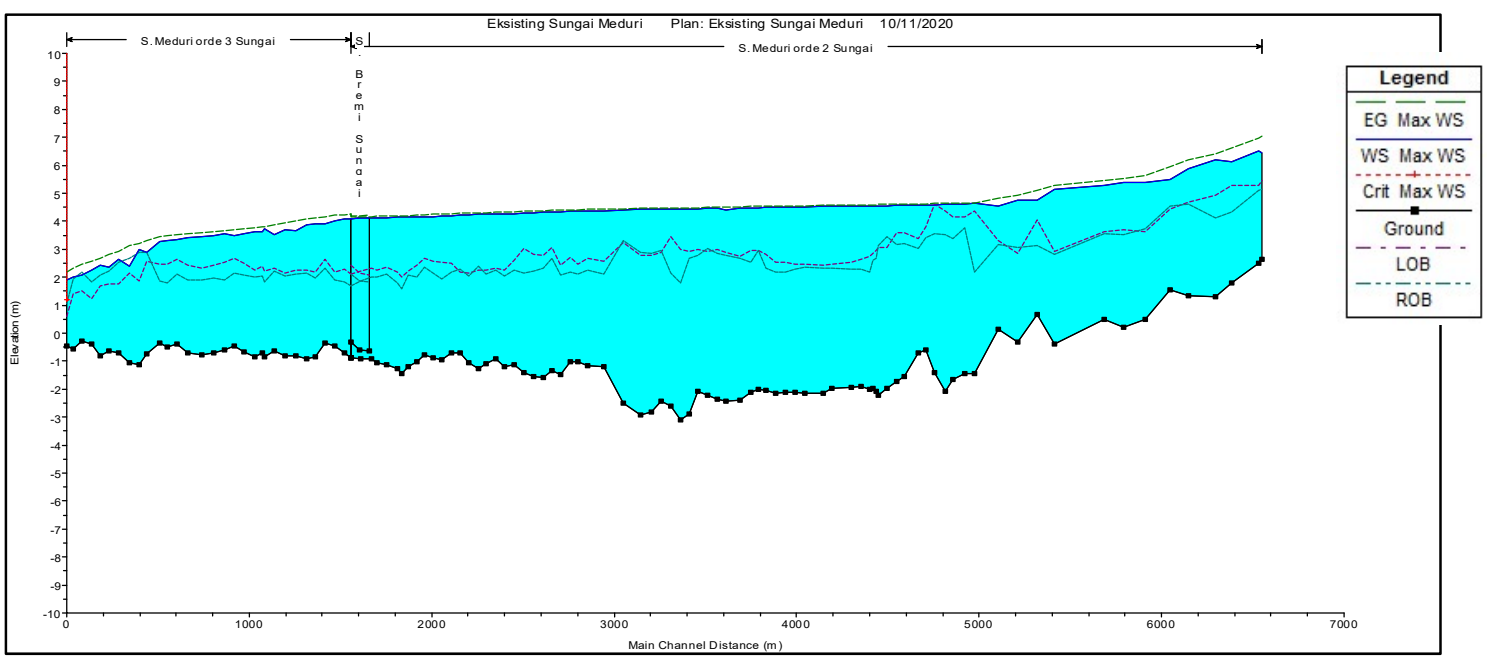

Gambar 5. Potongan memanjang hasil running eksisting

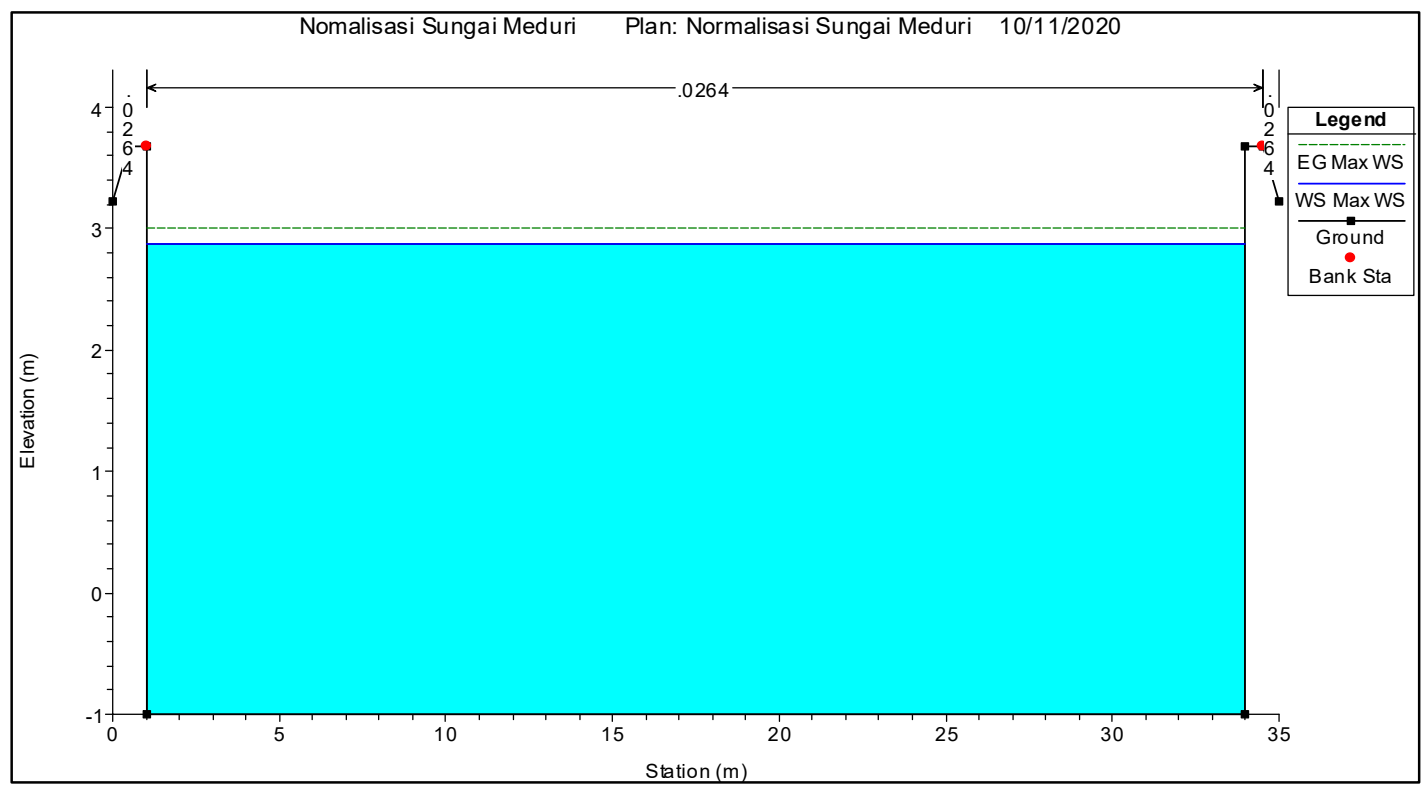

Gambar 6. Patok M. 8 setelah adanya normalisasi.

Pada Gambar 6 diperlihatkan hasil running HEC-RAS kondisi desain dimana pada patok M8 tidak terjadi limpasan dengan adanya upaya Normalisasi, yaitu dengan cara pengerukan atau memperdalam dasar sungai dan dengan adanya dinding penahan di sisi kanan dan kiri sungai, sehingga menjadikan bertambahnya kapasitas sungai dalam mengalirkan debit banjir Q25 (kala ulang 25 tahun) yang terjadi. Tinggi muka air banjir berada pada elevasi +2.87 yang mana dengan upaya ini mampu menurunkan tinggi muka air banjir sebesar $2.28 \mathrm{~m}$. Tinggi dinding penahan perlu ditambahkan tinggi jagaan sebagai keamanan dari loncatan air sebagai akibat dari adanya tinggi energi air sungai. Pemakaian tinggi jagaan menyesuaikan besarnya debit banjir rancangan, dalam hal ini diperoleh angka sebesar $0.8 \mathrm{~m}$ (Sosrodarsono, 1984).

Pada Gambar 7 diperlihatkan potongan memanjang alur sungai Meduri pada kondisi desain secara keseluruhan. Setelah adanya upaya perbaikan alur sungai dengan adanya Normalisasi, aliran air sungai menjadi lebih teratur karena hambatan yang terjadi seperti pendangkalan dasar sungai pada 
muara telah dihilangkan. Upaya Normalisasi yang dimodelkan dinilai cukup efektif dalam rencana pengendalian banjir sungai Meduri, sebab input parameter yang dilakukan dengan $H E C-R A S$ telah sesuai dengan data kondisi lapangan.

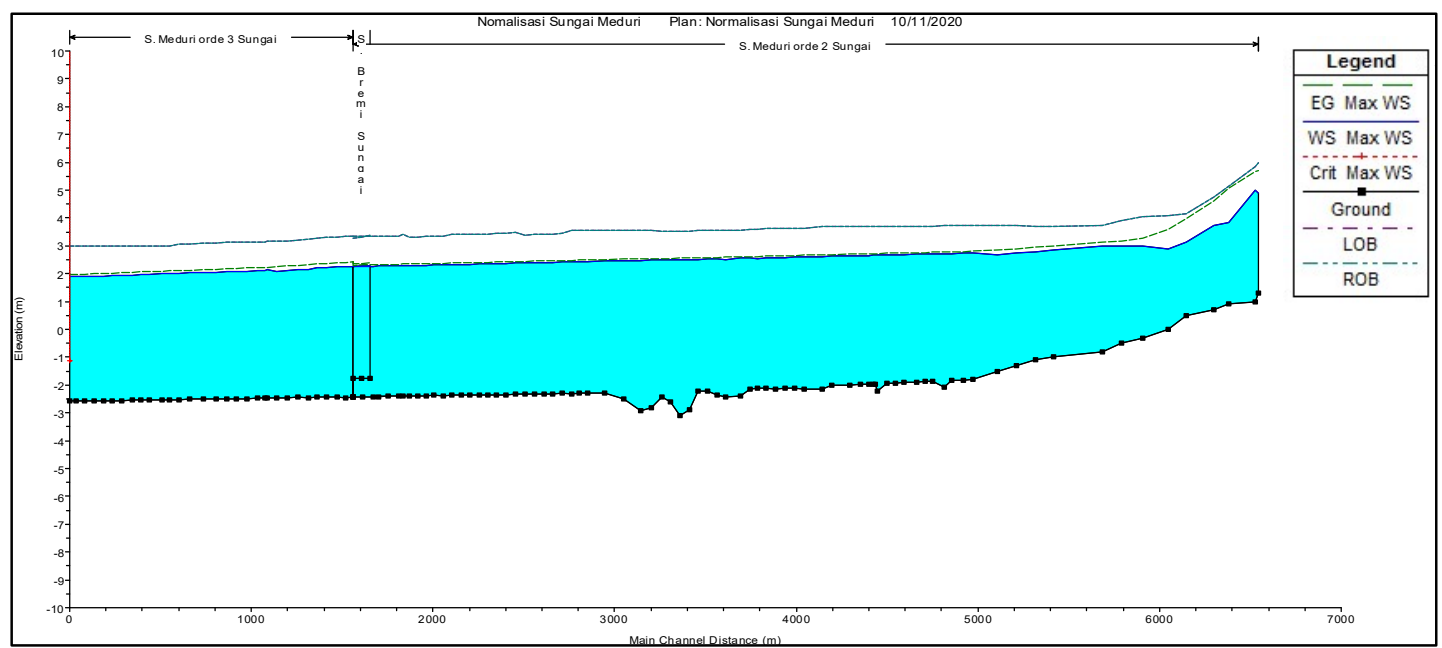

Gambar 7. Potongan memanjang hasil running desain

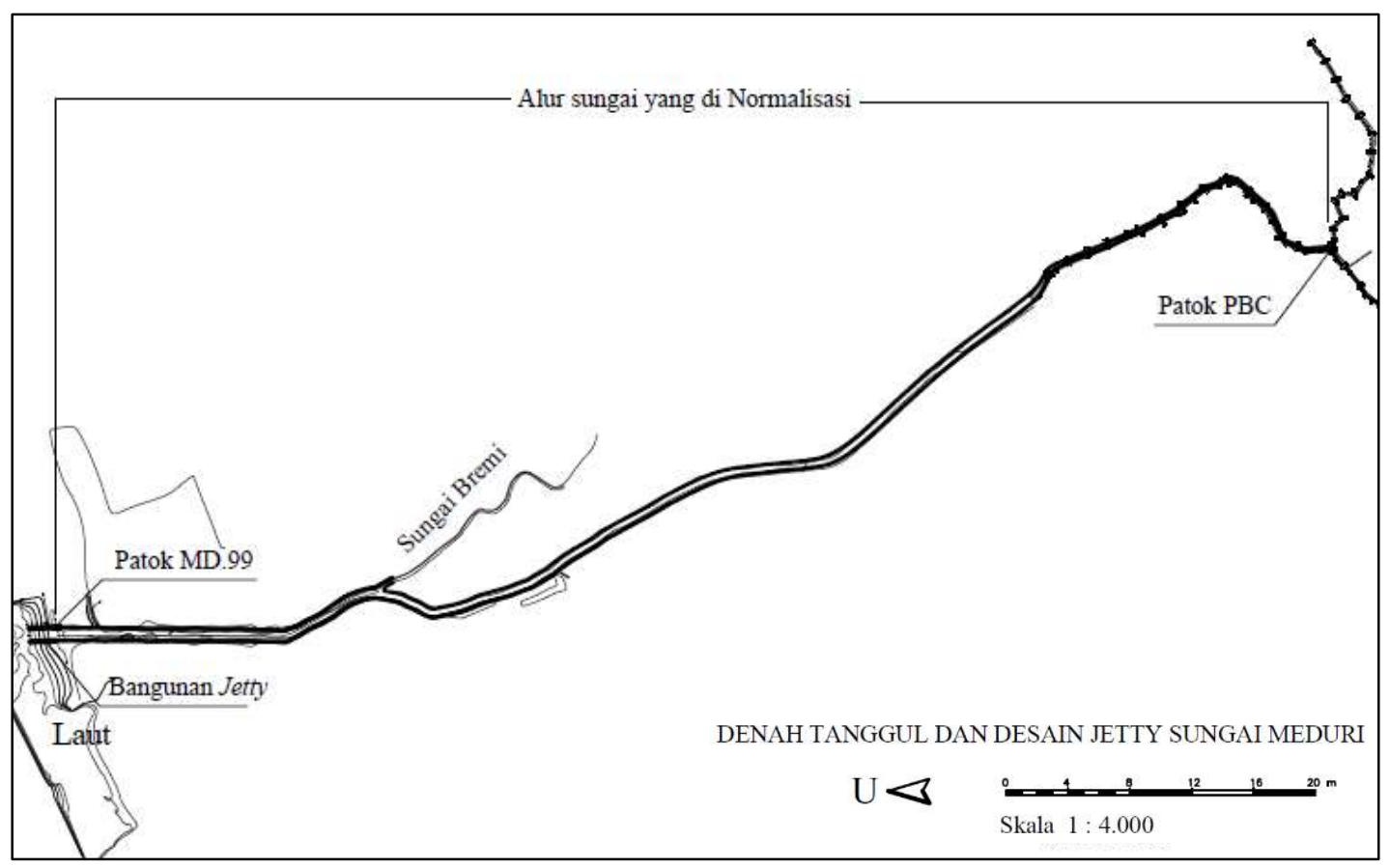

Gambar 8. Denah Situasi Tanggul Sungai Meduri

Gambar 8 merupakan gambar denah lokasi penanganan upaya banjir sungai Meduri. Panjang alur sungai yang dilakukan upaya Normalisasi adalah sepanjang $6.78 \mathrm{Km}$ dari patok PCB sampai patok MD.99. Dibagian hilir sungai yang berbatasan langsung dengan laur direncanakan adanya bangunan jetty atau pengarah aliran untuk mencegah adanya penumpukan sedimen pada muara.

\subsection{Perencanaan Dinding Penahan}

Dalam merencanakan bangunan dinding penahan memakai prinsip dari perhitungan dinding penahan tanah dengan struktur beton bertulang tipe kantilever. Direncanakan mutu beton adalah 25 Mpa dan mutu baja 400 Mpa. 


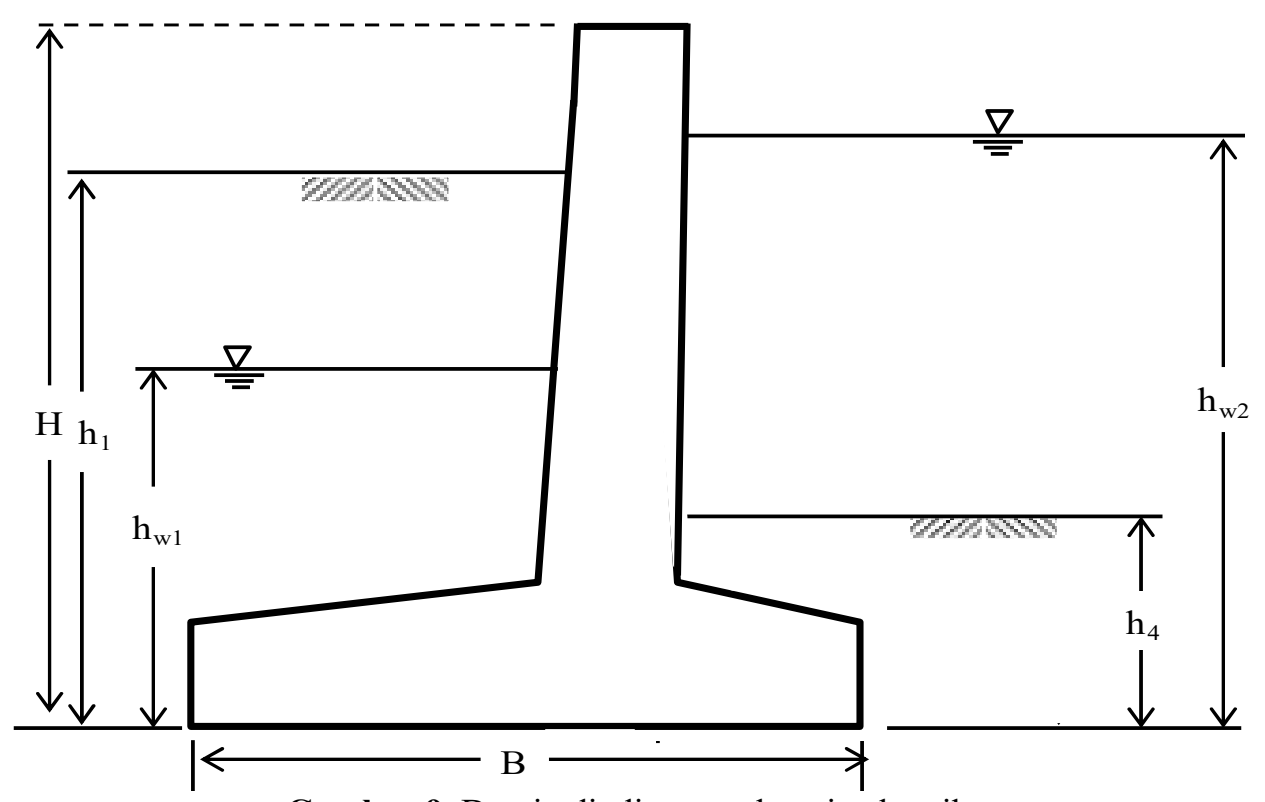

Gambar 9. Desain dinding penahan tipe kantilever

Dinding penahan direcanakan dengan lebar (B) $4 \mathrm{~m}$ dan tinggi (H) $7 \mathrm{~m}$. Pada analisa kekuatan diperhitungkan dalam panjang (L) $1 \mathrm{~m}$ karena strukturnya adalah menerus sepanjang sungai yang dilakukan Normalisasi. Tinggi air sungai yang digunakan adalah pada saat kondisi paling ekstrim yaitu pada kondisi banjir maksimum (hw2) yaitu $5.97 \mathrm{~m}$. Tinggi muka air tanah (hw1) diperhitungkan pada struktur bangunan dengan nilai $3.34 \mathrm{~m}$ serta timbunan tanah aktif (h1) direncanakan setinggi $6.5 \mathrm{~m}$ dan timbunan tanah pasif (h4) direncanakan setinggi $1.48 \mathrm{~m}$.

Parameter tanah juga sangat mempengaruhi kestabilan struktur bangunan. Dalam hal ini parameter seperti; berat volume tanah kering $\gamma_{\text {soil }}=1.64 \mathrm{t} / \mathrm{m}^{3}$, berat volume tanah saturated $\gamma_{\text {sat }}=1.88$ $\mathrm{t} / \mathrm{m}^{3}$, kohesi tanah $C_{B}=0.107 \mathrm{t} / \mathrm{m}^{2}$, Sudut geser tanah untuk tanah urugan $\phi=30^{\circ}$ dan sudut geser tanah untuk pondasi $\phi_{\mathrm{B}}=9.97^{\circ}$. Nilai-nilai tersebut digunakan untuk mendapatkan nilai Koefisien tanah dengan dikalikan nilai koefisien gempa $(\mathrm{Kh})$ sebesar 0.21 yang didapat dari peta percepatan puncak di batuan dasar untuk probabilitas 2\% dalam 50 tahun Kementrian Pekerjaan Umum dan Perumahan Rakyat (2017).

Perhitungan struktur dinding penahan yang ditampilkan pada Tabel 4 dikatakan aman (stabil) terhadap bahaya guling dan geser apabila memenuhi persyaratan yang telah ditetapkan pada BSN, 2017 SNI 8460:2017 tentang faktor keamanan minimum dinding penahan tanah. (NASIONAL, 2017).

Tabel 4. Rekapitulasi stabilitas bangunan

\begin{tabular}{lcc}
\hline \hline & \multicolumn{2}{c}{ Keamanan } \\
\cline { 2 - 3 } Kondisi & SF Guling & SF Geser \\
\hline Kosong-Normal & $4.09>2.0$ & $3.94>1.5$ \\
Kosong-Gempa & Aman & Aman \\
& $1.97>1.5$ & $1.38>1.25$ \\
Penuh-Normal & Aman & Aman \\
& $3.42>2.0$ & $1.61>1.5$ \\
Penuh-Gempa & Aman & Aman \\
& $57.44>1.5$ & $2.35>1.25$ \\
Rapid Drawdown- Normal & Aman & Aman \\
& $2.71>2.0$ & $1.72>1.5$ \\
Rapid Drawdown -Gempa & Aman & Aman \\
& $1.51>1.5$ & $1.54>1.25$ \\
\hline \hline
\end{tabular}


Perhitungan Kapasitas daya dukung tanah dilakukan untuk mengetahui beban yang diterima pondasi apakah menyebabkan keruntuhan bangunan atau tidak. Kondisi tanah lokasi studi yang termasuk lempung tidak padat, menyebabkan keruntuhan terjadi sebelum keseimbangan plastis tanah termobilisasi atau terjadinya keruntuhan geser lokal. Maka sebagai gantinya nilai $\mathrm{Nc}, \mathrm{Nq}$, dan $\mathrm{N} \gamma$ digunakan $\mathrm{Nc}^{\prime}, \mathrm{Nq}^{\prime}$, dan $\mathrm{N} \gamma^{\prime}$. dan nilai $\phi$ dan $\mathrm{c}$ dikalikan (2/3) dengan persamaan yang digunakan menurut teori Terzaghi (Hardiyatmo, 2003).

$$
\mathrm{q}_{\mathrm{u}}=\left(\mathrm{c}^{\prime} \times \mathrm{Nc}^{\prime}\right)+\left(\mathrm{Df} \times \gamma_{\text {soil }} \times \mathrm{Nq}^{\prime}\right)+\left(0.5 \times \gamma_{\text {soil }} \times \mathrm{B} \times \mathrm{N} \gamma^{\prime}\right)
$$

Dari persamaan di atas dengan nilai $\mathrm{Nc}^{\prime}, \mathrm{Nq}^{\prime}$, dan $\mathrm{N} \gamma^{\prime}$ yang diperoleh dari tabel nilai-nilai faktor kapasitas dukung tanah Terzaghi, didapatkan nilai Kapasitas Dukung Ultimate / Ultimate Bearing Capacity of soil, $\mathrm{q}_{\mathrm{u}}=3.072 \mathrm{t} / \mathrm{m}^{2}$. Nilai ini perlu dikalikan faktor aman sebesar 3 (untuk kondisi Normal) dan sebesar 2 (untuk kondisi Gempa).

$$
\mathrm{q}=\frac{\Sigma \mathrm{W}}{\mathrm{B}} \times\left(1 \pm \frac{6 \times \mathrm{e}}{\mathrm{B}}\right)
$$

Dengan memakai persamaan 5 di atas nilai reaksi pondasi (tegangan tanah akibat beban vertikal) yang terhitung pada setiap kondisi stabilitas bangunan sebesar $18.541 \mathrm{t} / \mathrm{m}^{2}$ nilainya masih lebih besar dari kapasitas daya dukung ultimit $\left(\mathrm{q}_{\mathrm{u}}\right)=3.072 \mathrm{t} / \mathrm{m}^{2}$, sehingga tanah tidak cukup kuat menerima beban vertikal yang dapat menyebabkan keruntuhan geser lokal. Dalam mengatasi permasalahan seperti ini diperlukan perencanaan tiang pancang yang berfungsi untuk menyalurkan beban ke bagian tanah dalam.

\subsection{Perencanaan Tiang Pancang}

Tiang pancang direncanakan dengan jenis friction pile atau tiang tahanan gesek dikarenakan kondisi tanah pada lokasi studi yakni tanah lempung dengan butir-butir yang sangat halus (very fine grained) sukar dalam melarutkan air. Cara kerja tiang jenis ini adalah dengan meneruskan beban yang diterima tiang ke tanah melalui permukaan kulit (skin friction). Tiang direncanakan dengan jenis minipile dengan kemampuan tiang dianalisis kekuatan bahan sesuai spesifikasi yang dikeluarkan oleh PT. BRM Pile tahun 2017 dengan mengacu pada perhitungan struktur beton untuk bangunan gedung (Setiawan, 2015).

Tiang pancang jenis mini pile direncanakan dengan bentuk persegi dengan panjang sisi (D) $20 \times 20 \mathrm{~cm}$ dengan berat tiap tiang (W) sebesar $0.096 \mathrm{ton} / \mathrm{m}$, besar gaya aksial tiang $\left(\mathrm{P}_{\text {aksial }}\right) 52.99$ ton. Kekuatan tiang dihitung dalam panjang $1 \mathrm{~m}$ karena prinsip yang masih sama dengan dinding penahan yaitu strukturnya yang menerus sepanjang sungai. Tiang pancang dalam perhitungan tiap panjang 1 $\mathrm{m}$ terdapat 4 buah yang dipancang sedalam $(\mathrm{H}) 12 \mathrm{~m}$ pada nilai N-SPT 10.

Analisis mengenai perhitungan pembagian tekanan pada kelompok tiang dilakukan dengan cara menghitung beban vertikal berupa sentris yang ditambahkan dengan momen. Dalam perhitungan yang digunakan adalah pada kondisi Kosong-Normal, yang mana merupakan beban vertikal yang paling besar $\left(\mathrm{V}_{\max }\right)=39.55$ ton dan nilai eksentrisitas $(\mathrm{e})=0.292 \mathrm{~m}$. Didapatkan nilai Momen (Mx) sebesar 11.27 ton.m

Perhitungan keamanan tiang pancang/gaya aksial maksimum terhadap pembebanan satruktur di atasnya digunakan persamaan di bawah ini (Sardjono, 1988).

$$
\mathrm{P}_{\max }=\frac{\sum \mathrm{V}}{\mathrm{n}}+\frac{\mathrm{M}_{\mathrm{X}} \mathrm{x} \mathrm{X}_{1}}{\sum \mathrm{X}^{2}}
$$

Nilai gaya aksial yang dihasilkan dinyatakan aman dengan nilai sebesar 13.27 ton masih lebih kecil dari nilai besar gaya aksial tiang yang sebesar 52.99 ton (Sardjono, 1988).

Faktor keamanan lain yang digunakan dalam merencanakan tiang pancang adalah menghitung kapasitas ultimit tiang dengan memperhatikan nilai N-SPT terhadap tiang. Digunakan persaman Meyerhof 1956 dengan luasan dasar tiang $(\mathrm{Ab})$ sebesar $0.04 \mathrm{~m}^{2}$ dan luas selimut tiang (As) sebesar $9.6 \mathrm{~m}^{2}$.

$$
\mathrm{Qu}=40 \mathrm{Nb} \mathrm{Ab}+0,5 \mathrm{~N} \times \mathrm{As}
$$


Diperoleh nilai kapasitas ultimit tiang sebesar 49.6 ton. Nilai ini perlu dibagi dengan keamanan sebesar 3 agar memperoleh nilai kapasitas daya dukung ijin tiang. Nilai kapsitas dukung ijin tiang dikatakan aman karena nilai daya dukung tiang masih lebih besar dari gaya aksial dengan nilai sebesar 13.27 ton (Sardjono, 1988).

Perhitungan defleksi tiang metode Broms digunakan untuk menghitung pergeseran horizontal tiang lateral. Pada lokasi studi ini diketahui bahwa jenis tanah adalah lapisan tanah kohesif dimana nilai Koefisien horizontal $(\mathrm{Kh})$ didapat dari tabel nilai yang disarankan oleh Terzaghi sebesar 200. Dengan mengalikan besar gaya horizontal $(\mathrm{H})$ sebesar 15.09 ton dan $\beta$ sebesar 0.218 , besarnya nilai defleksi tiang dapat dicari menggunakan persamaan di bawah (Tomlinson, 1980).

$$
\mathrm{y}_{0}=\frac{\mathrm{HX \beta}}{\mathrm{Kh} \times \mathrm{d}}
$$

Besarnya nilai defleksi tiang pancang yang dihasilkan sebesar $2.06 \mathrm{~cm}$, karena nilainya defleksi kurang dari linch $(1 \mathrm{inch}=2.54 \mathrm{~cm})$ maka perhitungan menenuhi persyaratan (Tomlinson, 1980).

\subsection{Analisis Beton Bertulang}

Setiap komponen struktur dirancang mampu memikul beban yang lebih besar agar memiliki keamanan terhadap kegagalan struktur, maka dari itu beban perlu dikalikan faktor beban 1.2 untuk beban mati dan 1.6 untuk beban hidup (Setiawan, 2016). Adapun dalam merencanakan beton bertulang, digunakan baja tulangan dengan kekuatan leleh fy $=400 \mathrm{MPa}$ (baja ulir) dan dengan kuat tekan beton $\mathrm{f}^{\prime} \mathrm{c}=25 \mathrm{Mpa}$. Umumnya dalam merencanakan beton bertulang untuk bangunan air dimensi cenderung lebih tebal dari bangunan darat, dikarenakan retak akibat suhu dapat terjadi akibat dari kenaikan suhu meskipun air di lingkungan sekeliling mampu menurunkan suhu. Untuk memperoleh kebutuhan penulangan yang kuat dan ekonomis, tulangan dibagi menjadi empat bagian besaran momen lentur, yaitu bagian A-A (dinding bagian atas), bagian B-B (dinding bagian bawah), bagian C-C (ujung kaki atau toe), dan bagian D-D tumit atau heel). Dalam merencanakan bangunan keairan, tulangan susut dan suhu (tulangan horizontal) diperlukan sebagai perlindungan sisi terluar bangunan dari pengaruh dari air dan panas. Sedangkan sebagai penumpu tulangan horizontal diperlukan tulangan vertikal pada dinding sisi terluar.

\subsection{Rencana Anggaran Biaya}

Dalam menghitung Rencana Anggaran Biaya (RAB) diperlukan daftar harga bahan dan upah kerja yang sesuai dengan kebutuhan konstruksi. Daftar ini diperoleh dari Standar Biaya dan Harga Satuan Kabupaten Pekalongan tahun 2019.

Analisis yang dilakukan setelah mendapatkan daftar-daftar adalah menghitung harga satuan pekerjaan yang dibedakan pada setiap pekerjaan, seperti mobilisasi alat, penulangan, beton K-225 dan seterusnya. Nilai koefisien pada setiap pekerjaan mengacu pada Permen PU No 112013 Pedoman Bahan Konstruksi Bangunan dan Rekayasa Sipil - Bidang Sumber Daya Air yang digunakan untuk menghitung Rencana Anggaran Biaya (Umum, P. M. P., \& Rakyat, 2013).

Uraian pekerjaan dibagi menjadi dua bagian utama, yaitu Pekerjaan Persiapan dengan jumlah harga yang dibutuhkan sebesar Rp 1,146,153,739 serta Pekerjaan Pengendalian banjir (Normalisasi dan Dinding Penahan) sebesar Rp 141,474,119,799. Kedua jumlah harga disatukan dengan penambahan PPN sebesar 10\% maka besarnya Rencana Anggaran Biaya yang dibutuhkan dalam menangani permasalahan banjir Sungai Meduri dengan panjang $6.78 \mathrm{Km}$ adalah sebesar Rp 156,88,300,000 (Seratus Lima Puluh Enam Milyar Delapan Ratus Delapan Puluh Dua Juta Tiga Ratus Ribu Rupiah). 


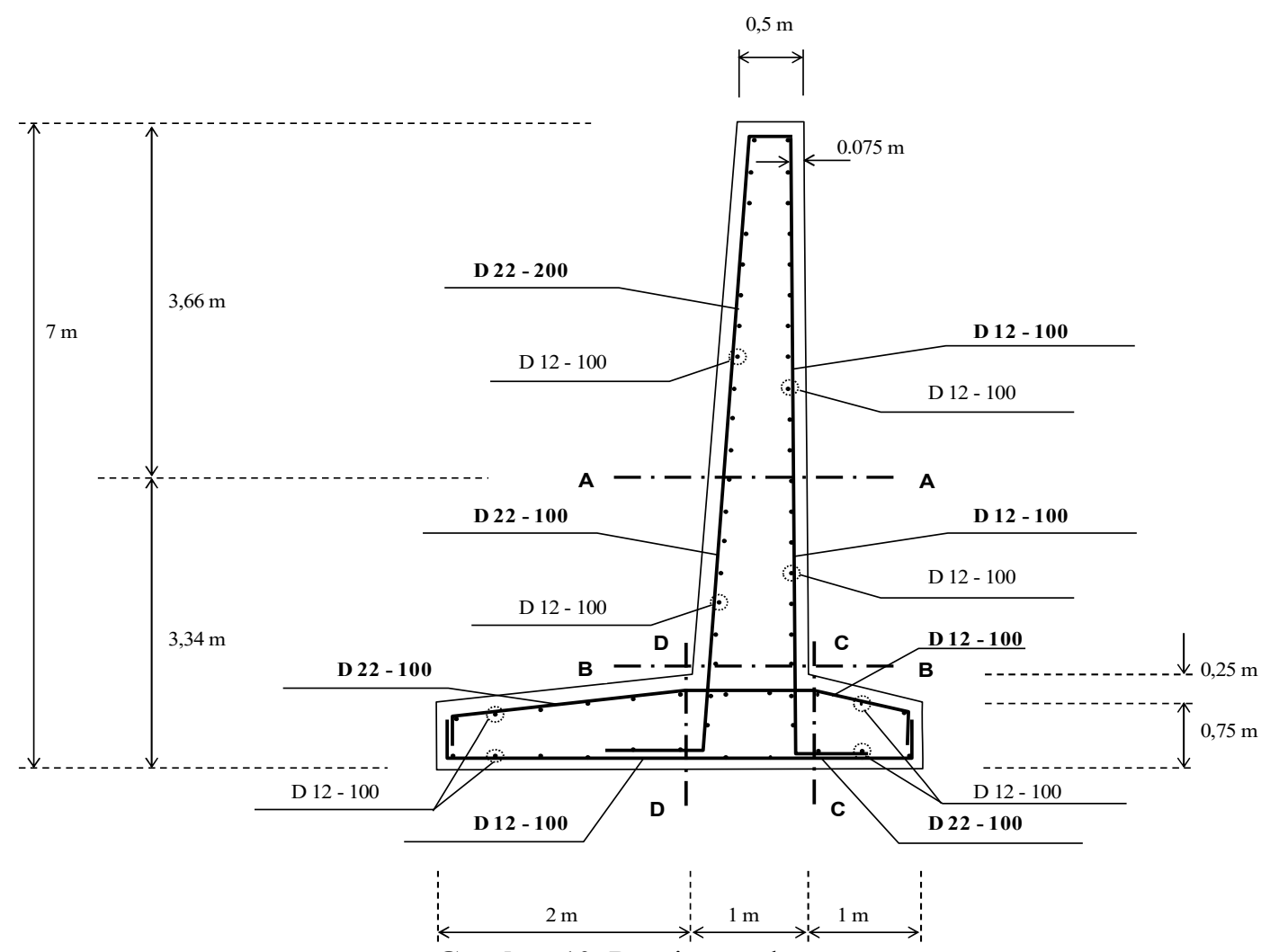

Gambar 10. Desain penulangan

\section{Kesimpulan}

Berdasarkan analisis Hidrologi pada Sub DAS Meduri-Bremi yang dilakukan, diperoleh nilai debit banjir rancangan kala ulang Q25 sungai Meduri yang cukup besar yang digunakan dalam pemodelan $H E C-R A S$. Hasil pemodelan eksisting didapati sungai meduri terjadi limpasan $2.22 \mathrm{~m}$ dan sehingga perlu dilakukan upaya pengendalian banjir dengan desain bangunan pengendalian banjir adalah dinding penahan tipe kantilever dengan tinggi $7 \mathrm{~m}$. Dengan pemodelan $H E C-R A S$ kondisi desain ini didapatkan sungai Meduri tidak terjadi limpasan kembali.

Perhitungan stabilitas bangunan dinyatakan aman terhadap segala kondisi, yakni kondisi kosong-normal, kondisi kosong-gempa, kondisi penuh-normal, kondisi penuh-gempa, kondisi rapid drawdown-normal, dan kondisi rapid drawdown-gempa. Konstruksi beton bertulang memiliki kuat tekan beton $\mathrm{f}^{\prime} \mathrm{c}=25 \mathrm{Mpa}$ atau K225 dan baja tulangan dengan kekuatan leleh fy $=400 \mathrm{Mpa}$. Perhitungan penulangan terdiri dari tulangan Utama/lentur (Potongan A-A dan Potongan B-B merupakan bagian dinding, Potongan C-C merupakan bagian kaki/toe, dan Potongan D-D merupakan bagian tumit/heel). Perhitungan Tulangan Horizontal sebagai tulangan susut dan suhu, serta perhitungan tulangan Vertikal sebagai penumpu tulangan horizontal. Kebutuhan tiang pancang jenis mini pile berdimensi $20 \times 20 \times 1200$ atau dengan bentuk persegi dengan lebar $0.2 \mathrm{~m}$ dan tinggi $12 \mathrm{~m}$ dengan jarak tiap tiang pancang adalah $1 \mathrm{~m}$. Perhitungan Rencana Anggaran Biaya (RAB) yang diperlukan dalam upaya pengendalian banjir sungai Meduri adalah sebesar Rp. 156,882,300,000.00.

\section{Ucapan Terimakasih}

Ucapan terimakasih disampaikan kepada Bapak Bambang Pari Purwanto, ST. M.T selaku Pemilik PT. Amarta Group Consultant Engineering yang telah mengijinkan penulis untuk meminta dan mengumpulkan data-data teknik yang digunakan dalam perhitungan studi ini. 


\section{Daftar Pustaka}

Army Corps of Engineers. (2010). Hydrolic Reference Manual HEC-RAS 4.0. California: U.S. Army Corps of Engineers.

Asdak, C. (1995). Hidrologi dan Pengolahan Daerah Aliran Sungai. Gajah Mada Universuty Prees.

C. D. Soemarto. Ir. B.I.E. DIPL.H. (1995). Hidrologi Teknik Edisi Ke - 2. Erlangga : Jakarta.

Chow, V. Te. (1985). Hidrolika Saluran Terbuka (Open Channel Hydraulics). Jakarta: Erlangga.

Hardiyatmo, H. C. (2003). Mekanika Tanah II. Gadjah Mada University Press, 91(5), 1-398.

Kasbullah, A. A., Lingkungan, J. G., Geografi, F., \& Mada, U. G. (2014). Geoedukasi Volume III Nomor 2, Oktober 2014, Kasbullah, A.A. danM.A. Mar fa'i, 83 - 91 83. Jurnal Geoedukasi, III(2), 83-91.

http://jurnalnasional.ump.ac.id/index.php/GeoEdukasi/article/view/562

Kodoatie, R. J., \& Syarief, R. (2010). Tata Ruang Air. Yogyakarta : Andi, 538.

Badan Standarisasi Nasional, B. S. (2017). SNI 8460: 2017 Persyaratan Perancangan Geoteknik. Jakarta: Badan Standarisasi Nasional.

Nasrullah, R. (2013). Cyber Media. Yogyakarta: IDEA Press, 76.

Sardjono, H. S. (1988). Pomdasi Tiang Pancang Jilid 2. Sinar Wijaya Surabaya.

Setiawan, A. (2015). Persyaratan Desain Komponen Struktur Lentur Beton Bertulang Tunggal antara SNI 03-2847-2002 dan SNI 2847-2013. Teknik Dan Ilmu Komputer, 4.14, 31-42.

Setiawan, A. (2016). Perancangan Struktur Beton Bertulang Berdasarkan SNI 2847: 2013. Jakarta: Erlangga.

Soewarno. (1995). Hidrologi. Bandung : Nova, 1-27.

Sosrodarsono, S. (1984). Perbaikan dan Pengaturan Sungai. Jakarta Pusat: P.T. Pradnya Paramita.

Syarifudin, A., et al. (2017). Hidrologi Terapan. Andi.

Tomlinson, M. . (1980). Pile Design and Construction Practice. New York: E \& FN SPON.

Umum, P. M. P., \& Rakyat, P. (2013). Pedoman Analisis Harga Satuan Pekerjaan Bidang Pekerjaan Umum. Peraturan Menteri Pekerjaan Umum, (11).

Umum, D. P. (2016). Penyusunan Review RPIJM Bidang Cipta Karya Kabupaten Pekalongan 2016. Direktorat Jenderal Cipta Karya.

Utama, laporan. (2017). Pekerjaan Detail Desain Pengendalian Banjir dan Rob Pekalongan dengan Kontrak Nomor: 05/KU.03.01-Ao.6.2/PERPROG-BBWSPJ/KNT/2017 Tanggal 28 Februari 2017, Tahun Anggaran 2017. PT. Suwanda Karya Mandiri. 